\title{
Preface. The XIV International Research and Practice Conference "Ukrainian School of Mining Engineering" (USME 2020)
}

\author{
Gennadiy Pivnyak ${ }^{1}$, Volodymyr Bondarenko ${ }^{2}$, Iryna Kovalevska ${ }^{2}$, Roman Lysenko ${ }^{2 *}$, and \\ Olha Malova ${ }^{2}$ \\ ${ }^{1}$ Dnipro University of Technology, Department of Power Engineering, 19 Yavornytskoho Ave., \\ 49005 Dnipro, Ukraine \\ ${ }^{2}$ Dnipro University of Technology, Department of Mining Engineering and Education, \\ 19 Yavornytskoho Ave., 49005 Dnipro, Ukraine
}

\begin{abstract}
The XIV International Research and Practice Conference "Ukrainian School of Mining Engineering" once again has made an important contribution to the mining industry, science and education. In the course of the conference, a wide range of problems was discussed: theoretical aspects of mining; domestic and foreign experience; personnel training in modern realities; problems of mineral deposits development; fundamental concepts of labor safety, etc. Fruitful dialogue and exchange of experience among conference participants contribute to the generation of new ideas, discoveries, technologies that will find their application in the nearest future. The formation of a new generation of scientists and engineers is taking place today, and therefore this representative conference is an important means of creating a new intellectual environment. The conference promotes the establishment of effective contacts between representatives of different scientific schools and directions, and the acquisition of invaluable experience and practice by researchers.
\end{abstract}

\section{Introduction}

We have the great honor to welcome you at the XIV International Research and Practice Conference "Ukrainian School of Mining Engineering" (USME 2020).

Ukrainian School of Mining Engineering is the annual event that brings together a large number of scientists, young researchers, industry and business representatives. All these people represent the mining and energy sectors and contribute to the advancement of technology and optimization of mineral development. The work of the conference is supported and approved by the management of the coal industry, companies, joint-stock companies, mines, enterprises and institutes. According to the results of the exchange of advanced achievements in technology of mining, participants of the conference unanimously supported the decision to recommend to the mining enterprises and organizations new scientific and technical developments.

\footnotetext{
*Corresponding author: rom.lysenko.23@gmail.com
} 
Despite the difficult situation in the world in connection with COVID-19 pandemic, the USME 2020 conference was held in accordance with the regulations and at the scheduled dates. The favorable situation in terms of the percentage of sick people and the absence of a quarantine regime in Ukraine made it possible to ensure the direct face-to-face presence of people at the conference. Traditionally, the Ukrainian School of Mining Engineering was held on the shores of the Azov Sea in the Berdiansk resort town in the "Slavutych" boarding house. Unfortunately, our foreign friends and colleagues, as well as some new foreign participants, could not come to the conference due to active quarantine in their countries. Thus, the conference was held in the mixed form of live reports and online presentations.

\section{Purpose and objectives of the conference}

Each USME [1 - 5] takes the most topical issues and shares the latest developments in the industry. Due to this, it is possible not only to adjust to the realities of the current situation in the mining and energy areas, but also to look into the future and predict further development of industry and technology, becoming the most successful in their business. Thus, this year's conference addressed the following topical issues:

- Digital transformation in mining industry;

- Digitalization in the mining industry. 3D visualization. Experience of use in mining companies RiO Tinto and Anglo American;

- Experience of the development of artificial intelligence technologies in mining;

- The use of virtual copies of planned, current and future states of a mining object based on digital twin technology;

- Mining mechanical engineering;

- Major coal mining trends in the world;

- Alternative energy sources;

- Reuse of mine workings as systems of support and security elements based on geomechanics problems solutions;

- Digitalization of closed mines for optimization technological, ecological and social problems;

- The use of geothermal energy of closing mines. Heat pumps;

- Safety of mining, sanitation and labor protection;

- New technologies for mine workings maintaining and supporting;

- Coal mining with maternal ash. Waste rocks backfilling in the mine;

- Auger technology of coal mining from pillars;

- Gas hydrate technology of coalbed methane utilization;

- Domestic and foreign experience of using borehole underground coal gasification;

- The issue of coal and ores enrichment;

- Regulatory requirements for the implementation of rescue operations at mining enterprises;

- Scientific and technical problems of mining of iron, manganese, uranium and other ores;

- Innovative solutions for open pit mining.

Presentation of the latest achievements in the field of mining engineering, solving acute mining problems, combination of innovative ideas of scientists and researchers with the practical experience of leading mining companies, unification of a community of likeminded people in one network for communication and ideas sharing, development of new areas of the mining business and the development of alternative energy sources, determination of the direction of the industry development vector, all these are the objectives that are achieved by conducting the USME. 


\section{Results of the conference}

Representatives of the coal and mining industries of Ukraine, Poland, South Africa, etc. took part in the conference, made reports and published scientific materials. Among them: Ministry of Energy and Coal Industry of Ukraine, Ministry of Education and Science of Ukraine, National Academy of Sciences of Ukraine, LLC "DTEK Energy", PJSC "DTEK Pavlohradvuhillia", LLC "DTEK Dobropilliavuhillia", MM "Heroiv Kosmosu", MM "Dniprovske", MM "Pavlohradske", MM "Bilozerske", MM "Pershotravenske", MM "Dobropilske", MM "Ternivske", PJSC "Donetsksteel" - Iron and Steel Works", LLC "Corum Group", PJSC "Kharkiv Machine Building Plant "Svitlo Shakhtarya", Elsta Elektronika Company (Poland), Pilog Group Company (South Africa), SE "Donetsk ExpertTechnical Center of State Labor", PJSC "DTEK Zhovtneva CEP", PJSC "DTEK Dobropilska CEP", Branch of "CEP Pavlohradska", LLC "CEP Kurakhivska", SE "Myrnohradvuhillia", State Militarized Mine Rescue Squad of the Coal Industry of Ukraine, Institute of Geotechnical Mechanics named by N. Poljakov of NAS of Ukraine, LLC "Mokrianskyi Stone Quarry No.3", PJSC "Novopoltavskyi Stone Quarry", LLC "Motronivskyi Mining and Processing Plant", PJSC "Dnipropetrovsk Aggregate Plant", LLC SPE "Standard", Mining Tool Factory LLC "Tehpostachannia", Dnipro University of Technology, National Technical University "Kharkiv Polytechnic Institute", LLC "Association of Coal Enterprises", and others.

The work of the conference began with the opening ceremony. Welcoming speeches were made by V. Bondarenko (Head of the Department of Underground Mining of Dnipro University of Technology, Doctor of Technical Sciences, Professor), M. Barabash (Director of the Department of Coal Production of LLC "DTEK Energy", Ph.D.), I. Salyeyev (Chairman of the Board of PJSC "Dnipro Metallurgical Plant") and M. Potapov (CEO of the "Corum Group" Company). The opening speech was as follows:

"We are honored to welcome you at the XIV International Research and Practice Conference "Ukrainian School of Mining Engineering".

The experience of civilization development shows that science and production play an essential role in ensuring sustainable development of society, belong to the key factors of economic reform and are guarantors of the national security. At the same time, this experience shows that preservation and care of scientific and production potential is a matter for every country. Awareness of this, provision of priority state support to science and production, increasing the prestige of work of mining specialists is very important in modern days. The mining community is hopefully expecting not only new steps of the country in this direction, but also, of course, implementation of previous decisions.

Our conference has always been attended by numerous representatives of young scientists and industrialists, who carry and increase the glory and greatness of mining, as well as being the driving force behind the strengthening and development of the country.

We have high expectations that despite the difficult and harsh realities of our time, the mining industry will still be enriched with innovative solutions. Implementation of these solutions will contribute to the improvement of the state of coal mining and enrich the state treasury with new achievements, which is the key to the prosperity of the country.

We wish all participants of the School good health, creative achievements and inspiration for new original ideas and implementation of your plans!'”

Then M. Barabash and M. Shyshov (Head of the Technical Development Department of the Coal Mining Directorate of LLC "DTEK Energy") made the first report on the topic "Security projects as part of the digital transformation" (Fig. 1). 

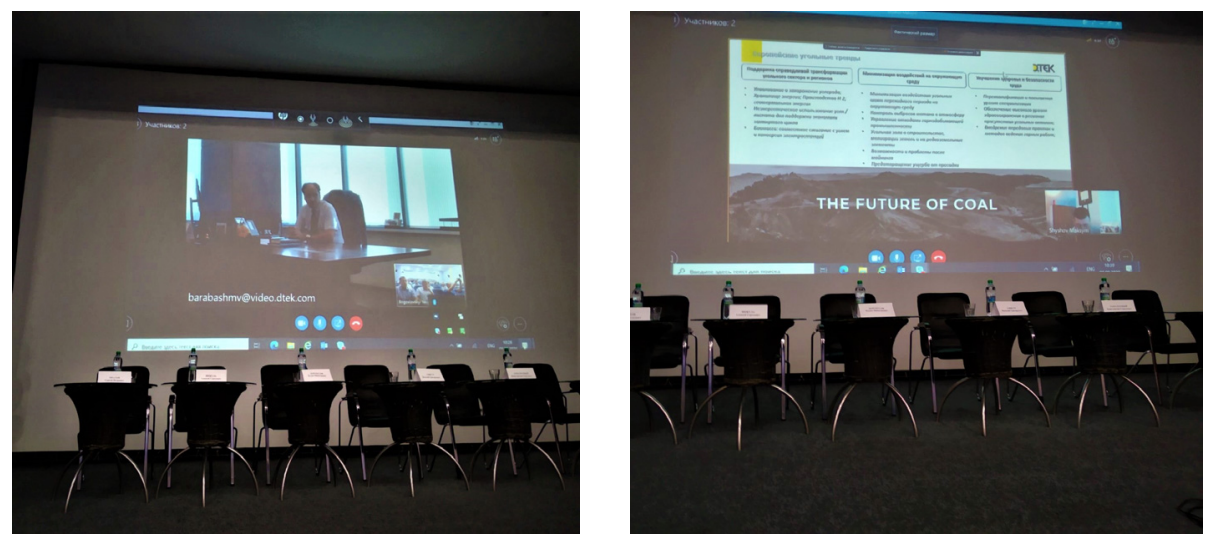

Fig. 1. First report by DTEK company representatives.

This year the conference held three panel discussions (Fig. 2) on the most pressing problems of mining industry:

1) "New mining equipment implemented at PJSC "Svitlo Shakhtaria".

The speaker was R. Berezhnyi - chief designer of the technical department of PJSC "Svitlo Shakhtaria". As a moderator was O. Kovalchuk - CEO of PJSC "Svitlo Shakhtaria".

2) "Complex processing of ashes from Prydniprovska combined heat and power plants, with obtaining raw materials for high-tech industries 4.0".

The speaker and moderator was V. Bondarenko - Doctor of Technical Sciences, Professor, Head of the Department of Underground Mining of Dnipro University of Technology.

3) "Mine closure. Technical and environmental problems of the Pavlohrad region".

The Speaker was D. Malashkevych - Ph.D., assistant of the Department of Underground Mining of Dnipro University of Technology. As a moderator was V. Bondarenko - Doctor of Technical Sciences, Professor, Head of the Department of Underground Mining of Dnipro University of Technology.
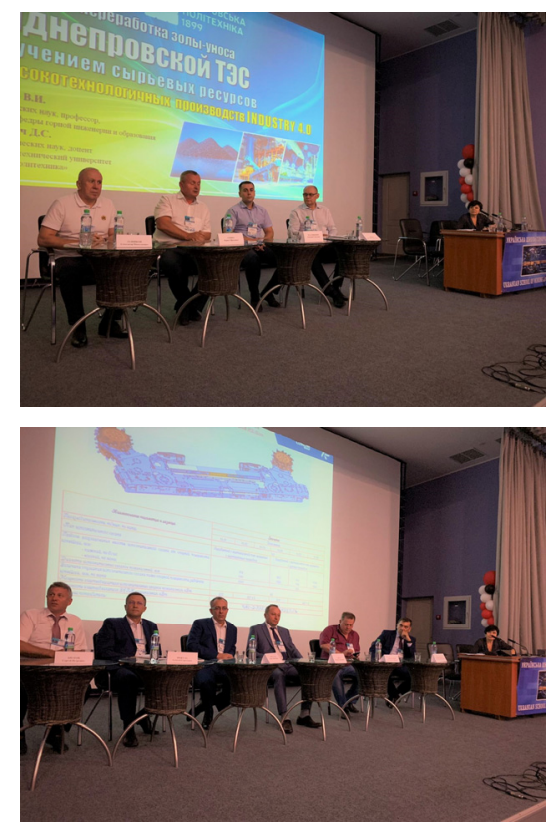
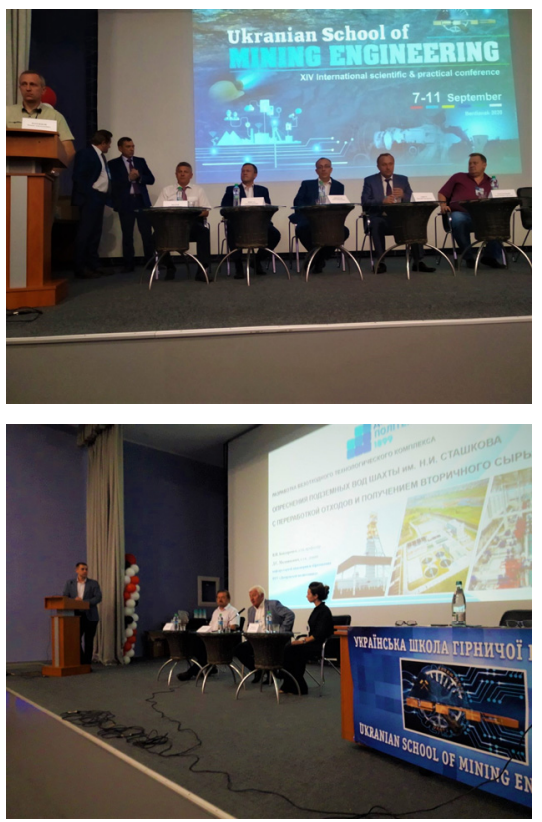

Fig. 2. Panel discussions that were held during the conference. 
In panel discussions presented their expert opinion the representatives of such companies as LLC "DTEK Energy", PJSC "DTEK Pavlohradvuhillia", PJSC "Donetsksteel", LLC “Corum Group”, etc.

After each panel discussion, conference participants were invited to make their presentations (Fig. 3). A large number of innovative approaches to solving urgent problems of the mining industry were noted. Each report was actively discussed, and the most relevant proposals were adopted. The main topics that were highlighted in the presentations were the following: monitoring and diagnostics of coal face systems operation; mining in the twenty-first century and its world of work; considerations for universities offering mining qualifications; processing of rock dumps; innovative systems of automatic maintenance of the roof of the stoping face; difficulties in maintaining shaft lining - testing methods and repair methods; development of technological schemes for open-pit mining of deposits using "mobile crushingreloading-conveyor complexes"; phenomenological model of an open-type geothermal system on the basis of oil-and-gas well; geomechanics of overworked mine working support resistance in the laminal massif of soft rocks; methane gas hydrates influence on sudden coal and gas outbursts during underground mining of coal deposits; and others.
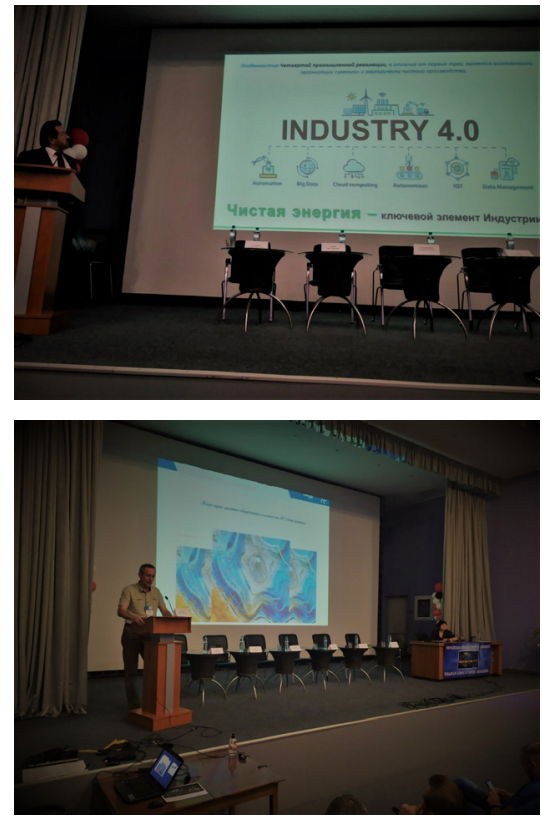
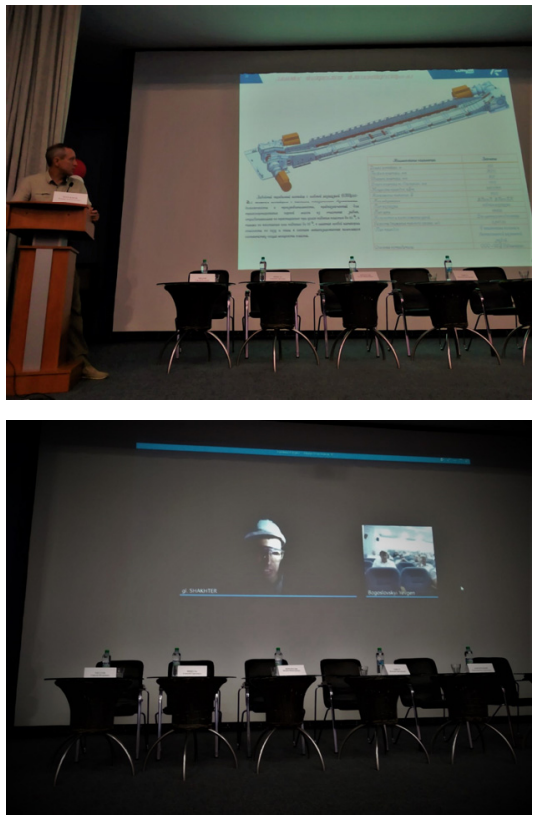

Fig. 3. Presentations of participants.

The summary of the "Ukrainian School of Mining Engineering" was held at the closing ceremony. By tradition, all new participants of the conference were awarded by commemorative signs as a symbol of belonging to the close-knit community of the School (Fig. 4). All participants presenting reports received certificates for participation in the work of the conference. Also at the ceremony, the resolution on decisions made on the basis of the results of the conference was approved. 

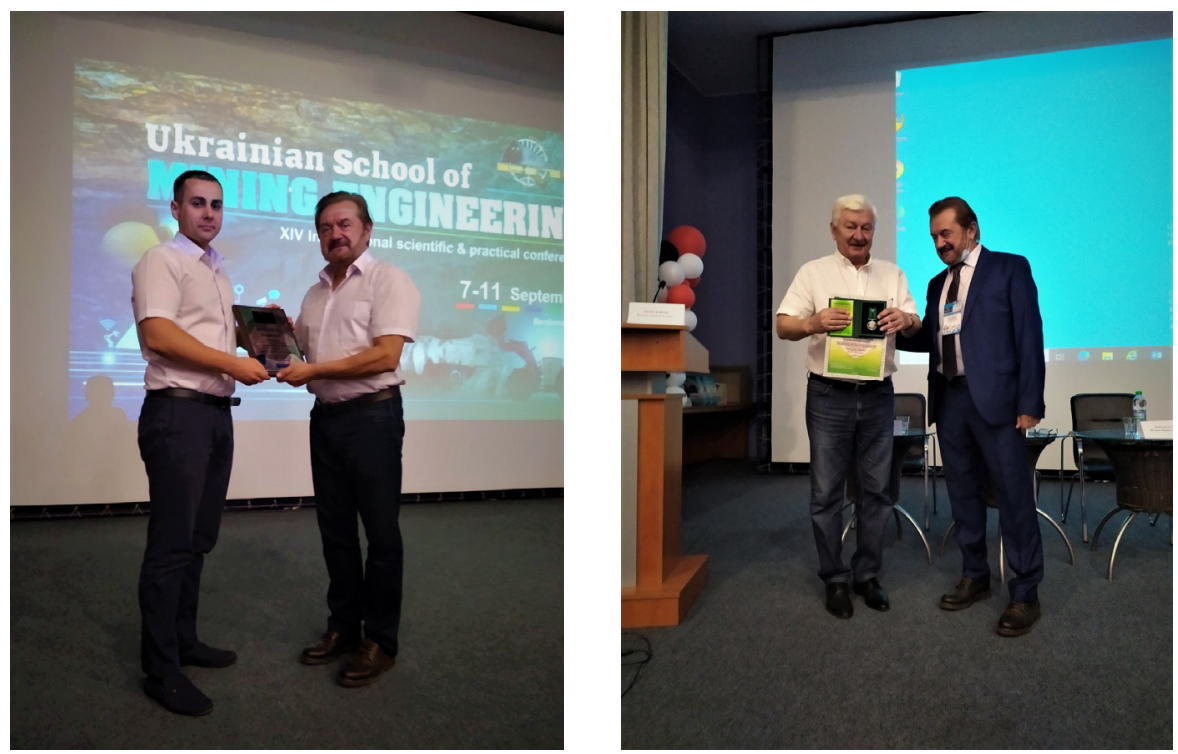

Fig. 4. Award ceremony for conference participants.

\section{The resolution}

The resolution of the XIV International Research and Practice Conference "Ukrainian School of Mining Engineering", which is adopted by the participants on September 10, 2020, proclaimed the following.

To express gratitude to the management of LLC "DTEK Energy", PJSC "Donetsksteel" metallurgical plant", LLC "Corum Group", as well as joint stock companies, enterprises and institutes for supporting the work of the conference and active participation in the exchange of advanced achievements in mining technology and techniques.

To expand the School's representation by participants that is a leader in advanced mining countries.

To recommend to the mining enterprises and organizations new scientific and technical developments such as:

- New projects of digital transformation of production processes;

- Complex processing of ash and slag materials of thermal power plants with obtaining raw materials for high-tech industries;

- Waste-free technology of demineralization of groundwater of mines with processing of desalination waste for obtaining of secondary raw materials;

- Automatic control systems for mechanized coal face systems;

- New mining equipment manufactured by LLC "Corum Group";

- Phenomenological model of open-type geothermal systems in the development of oil and gas fields;

- Two-stage scheme of hydroclassification of coal slime;

- Degasification schemes under conditions of uneven methane emission;

- Technologies of combined mounting of workings in areas of high rock pressure;

- Mathematical models for automation of production process databases;

- Ranking of high-loaded stoping faces;

- Mechanisms of development of dynamic modes of fluid injection under conditions of steep fall reservoirs development;

- Mechanization of preparatory work processes using the RH160 roadheader; 
- Explosion-proof transformer substations manufactured by LLC "Corum Group";

- Mobile overburdens in stoping faces;

- Use of high-pressure pumps in mining industry;

- Installation of support mounts for preparatory workings of a new technical level;

- Complex extraction and use of mineral resources;

- Mining of coal pillars by the complex of paired augers;

- Feasibility study of geothermal water development;

- Using the method for determining the parameters of the placement and mounting of the workings during the stoping operation;

- Using the algorithm for calculating the stress-strain state of the rock mass in the development of a set of flat-lying coal seams.

To recommend to Institute of Geotechnical Mechanics named by N. Poljakov of NAS of Ukraine to include in the new edition of the project "Regulations on the design of ventilation of coal mines" practical developments of DTEK specialists on the determination of safe mining of high-loaded gas faces.

It is recommended to hold panel discussions on the following issues: development of mining industry, mining operations safety in the conditions of gas-bearing coal seams development, new technologies of mining and processing of minerals, application of digital technologies of visualization and forecasting of economic indicators of mining enterprises functionality.

To hold from 6 to 10 September 2021 the anniversary XV International Research and Practice Conference "Ukrainian School of Mining Engineering".

\section{Conclusions}

Despite the ambiguous and rapid modern trends in the development of the energy sector in general, and coal industry in particular, it is quite obvious that there is a need for a balanced approach to strengthening energy security and consideration of national interests, first of all. Such issues are submitted for study and discussion at the XIV International Research and Practice Conference "Ukrainian School of Mining Engineering", annually providing an opportunity and basis for a reasonable assessment of the current situation and the formation of strategic directions.

The main criterion in forming the directions of development of the coal industry should be the objective reality regarding the economic and resource opportunities of a state, and therefore - the implementation of national energy interests in the course of inevitable globalization processes. Today it is obvious that sufficiently high volatility of price indices for energy resources, including alternative ones, leaves coal as the most reliable and cheapest source of energy. That is why the task of USME is to find the most optimal ways of further development of the coal industry in the context of a combination of national interests and global trends of the energy sector development.

The Organizing Committee and scientific editors express their gratitude to the publishing house EDP Sciences (France) and the scientific serial E3S Web of Conferences as a part of EDP Sciences for their assistance in publishing the materials of the International Research and Practice Conference "Ukrainian School of Mining Engineering" and indexing in the international scientific citation database Scopus.

\section{References}

1. V. Bondarenko, I. Kovalevska, R. Lysenko and O. Malova (2019). The XIII International Research and Practice Conference "Ukrainian School of Mining Engineering" as a step to the new direction of innovative technologies and intelligent systems in the mining industry. E3S Web of Conferences, (123), 00001. https://doi.org/10.1051/e3sconf/201912300001 
2. Bondarenko, V., Kovalevska, I., Lysenko, R., Malova, O., Cawood, F., \& Hardygora, M. (Eds.) (2018). Ukrainian School of Mining Engineering. E3S Web of Conferences, (60). Retrieved from https://www.e3s-conferences.org/articles/e3sconf/abs/2018/35/contents/contents.html

3. Bondarenko, V., Kovalevska, I., \& Ganushevych, K. (2014). Progressive technologies of coal, coalbed methane, and ores mining. The Netherlands, Leiden: CRC Press/Balkema. ISBN: 978-131574031-7; 978-113802699-5.

4. Pivnyak, G., Bondarenko, V., Kovalevska, I., \& Illiashov, M. (2012). Geomechanical Processes During Underground Mining: School of Underground Mining. The Netherlands, Leiden: CRC Press/Balkema. ISBN: 978-020307327-8; 978-041566174-4.

5. Pivnyak, G., Bondarenko, V., \& Kovalevska, I. (2011). Technical and Geoinformational Systems in Mining: School of Underground Mining. The Netherlands, Leiden: CRC Press/Balkema. ISBN: 978-020333266-5; 978-113811244-5. 